\title{
Selected climatic variables in Slovakia are favourable to the development of Dothistroma needle blight
}

\author{
Emília Ondrušková", Radovan Ostrovský, Zuzana Jánošíková, \\ Katarína Adamčíková, Marek Kobza
}

\begin{abstract}
Department of Plant Pathology and Mycology, Institute of Forest Ecology of the Slovak Academy of Sciences,
\end{abstract} Akademická 2, 94901 Nitra, Slovakia

\begin{abstract}
OndrušKová, E., Ostrovský, R., Jánošíková, Z., Adamčíková, K., KobZa, M., 2020. Selected climatic variables in Slovakia are favourable to the development of Dothistroma needle blight. Folia Oecologica, 47 (2): $144-152$.

Dothistroma needle blight (DNB) is a disease of pine needles. It causes significant defoliation of affected trees; intensive attacks lead to damages of the whole stand. The relationship of trends in disease severity and intensity with climatic variables were studied in three Austrian pine plantations (Jahodná, Kálnica, Litava) during 2014-2018. During the monitoring period, the greatest variability in disease severity was observed in the top third of the crowns, which showed the highest correlation with the variants of the most important climatic conditions (temperature and relative humidity) tested. For the spread of DNB, based on statistical assessment, a higher number of intervals of environmentally favourable climatic conditions is crucial. Both Dothistroma species (D. septosporum and D. pini), which are causal agents of the disease, were identified in Jahodná. In Kálnica and Litava, only D. septosporum was present.
\end{abstract}

\section{Keywords}

disease intensity, Dothistroma needle blight, relative humidity, temperature

\section{Introduction}

Dothistroma needle blight (DNB) is a worldwide disseminated disease caused by two different fungal species, Dothistoma septosporum (Dorogin) M. Morelet and D. pini Hulbari (BARNES et al., 2004). Symptoms of the disease include reddish spots, later becoming bands surrounding black erupment conidiomata (acervuli) on necrotic needles (BARNes et al., 2016). Asexual conidia are produced abundantly during wet periods of the growing season and are responsible for the rapid development of epidemics (HARRINGTON and WINFIELD, 1998). In Europe, the period from the second half of May until the end of June is critical for infection. The incubation period lasts about 2-4 months; by autumn, symptoms are clearly visible, and the conidia overwinter in infected needles to sporulate the following year (BROWN, 2003; JANKOvsKÝ et al., 2004).

Dothistroma needle blight has been reported for 76 countries, of which 35 are in Europe. The high incidence is not only a result of intensive survey and monitoring programs in the last few years (DRENKHAN et al., 2016), but also a likely response of DNB to favourable weather conditions (Woods et al., 2016). There are 109 known host taxa for Dothistroma species, 95 of which are within the genus Pinus, with variable susceptibility (DRENKHAN et al., 2016). Epidemics of DNB have occurred in Pinus 
radiata plantations of the southern hemisphere in the middle of the 20th century in Africa, Chile and New Zealand (Gibson et al., 1964; Gibson, 1972; GiLmour, 1967). The geographic range and intensity of DNB, particularly in the northern hemisphere, have increased dramatically since the late 1990s, where serious epidemics have occurred on Pinus nigra Arnold subsp. laricio (Poiret) Maire in Britain and on Pinus contorta var. latifolia Dougl. Loud in British Colombia, Canada (Brown et al., 2003; Woods, 2003; BradShaW, 2004; Brown and WebBER, 2008).

The first record of the disease in Slovakia was in 1996 (KunCA and FofFová, 2000); in many localities, a significant incidence of the disease was recorded in 2000-2002 (personal communication with foresters). Out of $2.02 \mathrm{mil}$. ha of forests in Slovakia, pine plantations account for $6.7 \%$. In addition, $1.1 \%$ is represented by native Pinus mugo (Správa o lesnom hospodárstve v Slovenskej republike za rok 2018, 2019), which mostly occurs at high elevations in protected areas, where it forms the forest cover. At the end of the 1980s, pines (including the highly susceptible introduced $P$. nigra) were widely planted in Slovak urban greenery, in Christmas tree plantations, but also in areas unsuitable for the cultivation of other species, such as areas with sandy soil and high ground water levels.

To enable a disease outbreak, the susceptible host, the appropriate environment and the pathogen's presence and its ecological requirements have to interact (GäUMANN, 1950). Many pathogens causing needle diseases are sensitive to precipitation and humidity, and their rates of reproduction, spread and infection are greater when conditions are moist (HARvell et al., 2002). Several studies have focused on the determination of optimal and/or suitable conditions for the spread of DNB and found various climatic variables (KARADZIC, 1994; Brown et al., 2012; DvořÁK et al., 2012). For dispersal of DNB pathogens, significant rainfall, leaf wetness and relative humidity $(\mathrm{RH})$ are necessary (BOATING and LEwIS, 2015). In another study, temperature was an important factor, while rainfall had a less significant effect on the infection intensity (KARADžIĆ, 1989). WooDs et al. (2005) report a relationship between increases in summer precipitation and DNB pathogen historical records. Rainfall is particularly critical for infection; the amount of summer rainfall and the rates of infection in the following year are positively correlated (BULMAN, 2007). Increases in the incidence and severity of the disease in areas where it has long been established and notable range expansions have both recently been observed. Given the rapid response of DNB to favourable weather conditions, it seems plausible that changes in disease behaviour could be due to climatic changes (Woons et al., 2016).

The objective of this study was to analyse the relationship of trends in disease severity and intensity with climatic variables. We analysed data on disease intensity (outbreak) and climatic variables and compared them over 5 consecutive years. In addition, we also characterised the causal pathogen species.

\section{Materials and methods}

\section{Study area and sampling}

We investigated three infected Pinus nigra (Austrian pine) stands situated in three different parts of SR, namely northwest (Kálnica), southwest (Jahodná) and south of central Slovakia (Litava, Fig. 1). The characteristics of the localities are given in Table 1.

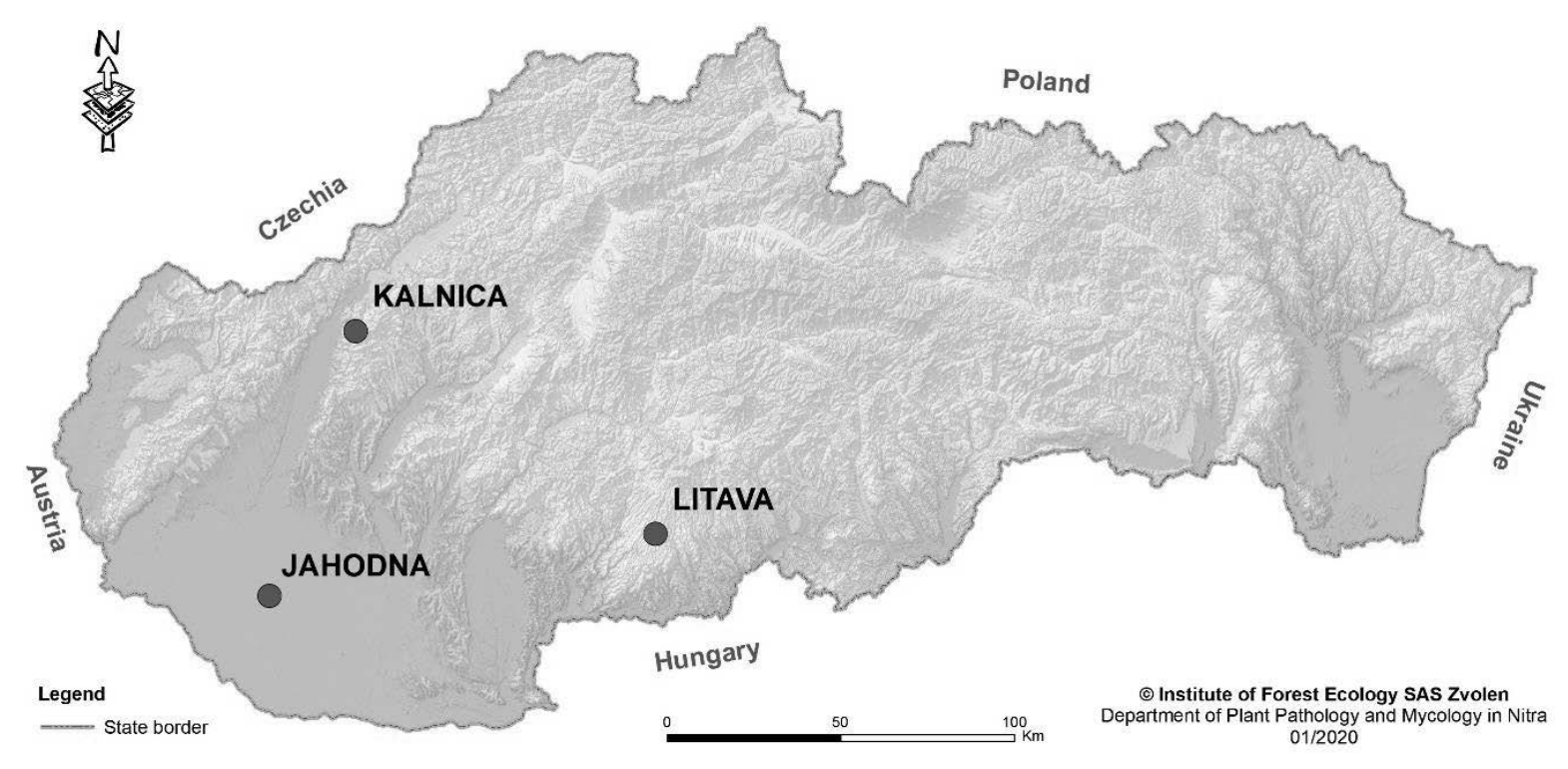

Fig. 1. Localization of evaluated localities in Slovakia. 
Table 1. Characteristics of evaluated localities

\begin{tabular}{|c|c|c|c|}
\hline & Jahodná & Kálnica & Litava \\
\hline Type of planting & Christmas tree plantation & Christmas tree plantation & Forest plantation \\
\hline Area (ha) & 2.8 & 1.0 & 4.8 \\
\hline Stand composition & $100 \%$ P. nigra & $100 \%$ P. nigra & $\begin{array}{c}15 \% \text { P. sylvestris } \\
35 \% \text { P. nigra } \\
\text { Picea, broadleaf }\end{array}$ \\
\hline Altitude (m asl) & 103 & $404-428$ & $438-458$ \\
\hline Coordinates (WGS 1984) & N 48.042883, E 17.727464 & N 48.762536, E 17.974826 & N 48.302102, E 19.179721 \\
\hline Slope $\left(^{\circ}\right)$ & 0.1 & $7.3-8.8$ & $9.3-19.0$ \\
\hline Seedlings provenance & Unknown & $\begin{array}{l}\text { Nursery } \\
\text { Kočovce }\end{array}$ & $\begin{array}{c}\text { Nursery } \\
\text { Vlčok, Krupina }\end{array}$ \\
\hline Host age (years)* & 25 & 15 & 25 \\
\hline DNB presence since & 2000 & 2002 & 2009 \\
\hline
\end{tabular}

*Host age was determined at the beginning of evaluation in 2014.

Symptomatic needles with apparent fruiting bodies were randomly collected from all three localities (Fig. 1) during the period 2013-2015 once a year. The presence of the disease was investigated based on characteristic symptoms described in the EPPO Bulletin (EPPO, 2015). At least 20 symptomatic needles were collected from each tree, maintaining a distance of $10 \mathrm{~m}$ in each direction between sampled trees. Several samples from each locality were collected. All collected needles were placed separately into paper bags, transported to the laboratory, stored at $-20^{\circ} \mathrm{C}$ and used for DNB species identification. Herbarium specimens were deposited in the Plant Pathology Herbarium of the Institute of Forest Ecology, Slovak Academy of Sciences (Nitra).

\section{Dynamics of disease intensity}

The method of Kirisits and Freinschlag (2012) was used to evaluate DNB disease intensity. The tree crown was divided into thirds, and each third was evaluated separately and assigned to one out of seven disease severity classes (classes 0-6), followed by recalculation of tree damage percentage; for details, see KIRISITS and FrEINSCHLAG (2012). The rating scheme of DNB symptoms was applied each year at the same time (April, May) from 2014 to 2018. We assessed the presence of symptomatic needles and defoliation. Thirty-five trees per plantation were selected randomly and evaluated independently by the same evaluator in each locality each year. Some individuals were eliminated for different reasons (eradicated) and excluded from the final analysis.

\section{Analysis and comparison of climatic data and disease intensity (outbreak)}

Battery-operated automatic dataloggers Minikin THi 25 (Environmental Measuring Systems, Czechia) were used in each experimental plot to measure climatic data (temperature and relative humidity). One datalogger was placed in the centre of each research locality, attached to a tree stem at a height of $2 \mathrm{~m}$ above the ground. Datalogger sensor accuracy was $\pm 0.15^{\circ} \mathrm{C}$ and $\pm 2 \%$ relative humidity. Climatic data were measured and collected hourly during the evaluation period.

Conditions suitable for the spread of DNB in research plots (temperature and relative humidity) were selected based on literature data. The recorded hourly data of temperature and relative humidity were processed by logical mathematical functions and logical operators (Microsoft Excel, Microsoft Inc.), with the aim to evaluate the following parameters: number of intervals per season (No), maximum duration of interval (hours), average interval duration (hours), sum of intervals per season (hours), sum of days per season (days). The selected parameters were evaluated yearly for each research plot (Table 2).

Final data were compared in terms of determining dependence of climatic conditions (represented by processed hourly data) on disease intensity (average per locality). Pearson's correlation analysis was performed to determine the linear correlation between variables/parameters.

Experimental variants of optimal temperature and relative humidity range for the spread of DNB, tested within three research plots, were selected and modified according

Table 2. Parameters evaluated within Variant V1. Dataloger records data from research plots, filtered and processed to fulfil temperature as well as relative humidity conditions for variant V1 in 2014

\begin{tabular}{cccccc}
\hline Locality & $\begin{array}{c}\text { Number of intervals } \\
\text { per season (No) }\end{array}$ & $\begin{array}{c}\text { Maximal duration } \\
\text { of interval (hours) }\end{array}$ & $\begin{array}{c}\text { Average interval } \\
\text { duration (hours) }\end{array}$ & $\begin{array}{c}\text { Sum of intervals } \\
\text { per season (hours) }\end{array}$ & $\begin{array}{c}\text { Sum of days per } \\
\text { season (days) }\end{array}$ \\
\hline Jahodná & 167 & 40 & 5.63 & 941 & 113 \\
Kálnica & 167 & 18 & 4.07 & 680 & 101 \\
Litava & 126 & 26 & 4.86 & 612 & 73 \\
\hline
\end{tabular}


to GADGIL (1974), Brown et al. (2012) and DvořÁK et al. (2012) and are shown in Table 3.

The statistical software SAS Enterprise Guide (ver. 6.1) was used for statistical analysis.

\section{Identification of DNB pathogen and mating types}

The DNB pathogens were identified based on DNA molecular methods. The DNA was extracted directly from pure cultures and/or infected needles. Dothistroma cultures were prepared by the spore-streaking technique using mature conidiomata, according to ONDRUŠKOvÁ et al., (2017) and JÁNOŠ́́KOvÁ-HečKovÁ et al. (2018). Threefour-week-old fungal colonies, grown on 3\% malt extract agar (MEA), were used for DNA extraction. For DNA extraction from infected needles, 7-10 pieces of the needle with conidiomata per sample after surface sterilisation with $96 \%$ ethyl alcohol were used. Two types of needle samples were analysed: conidiomata excised from (i) the same needle or (ii) from different needles. The DNA extraction was performed using the E.Z.N.A. Fungal Kit (Omega Bio-tec, Inc. USA) following the manufacturer instructions; extracted DNA was stored at $-80^{\circ} \mathrm{C}$. The species and mating type identification was performed by two multiplex sets of primers (GROENEWALD et al., 2007).

The PCR reaction mix and conditions are described in ONDRUŠKOvÁ et al. (2017) and JÁNOŠíKOvÁ-HeČKOvá et al. (2018).

\section{Results}

\section{Dynamics of disease intensity}

Using the rating system of KIRISITS and FreINSCHLAG (2012) to assess disease intensity, we found that mean disease intensity significantly increased between the first
(2014) and the last year (2018) of evaluation in each studied locality. Severity increased by $17.9 \%$ at Jahodná, $17.8 \%$ at Litava and $32 \%$ at Kálnica (Table 4). Although the initial assessment of disease severity in Kálnica was the lowest, the final assessment was the highest when compared with the two other studied localities.

In the first year of evaluation (2014), in Jahodná, Kálnica and Litava, two, zero and four trees, respectively, were damaged at more than $75 \%$, while in the last year (2018), the frequency was 14, 28 and 19, respectively.

Increase in disease intensity was recorded in all evaluated thirds of the crown and all localities. The most significant difference in rating of crown thirds during the studied years was observed in the upper third of the crown, which was therefore used for correlation analysis within variants and selected parameters. The downgrade of the visually evaluated class was similar in Jahodná and Litava localities, and the highest increase in disease intensity was recorded for Kálnica (Fig. 2).

Evaluation of 105 trees ( 35 trees/locality) showed that the initial disease intensity of the upper third of the tree deteriorated in 89 of the trees and in almost all of the trees in the middle third (97 trees). When assessing the lower third, the disease intensity deteriorated in the lowest number of trees (34). The intensity of the disease was, however, not changed after 5 years in 11 trees in the upper third, in 4 trees in the middle third and in 64 trees in the lower third. In several cases (16 in total), the intensity of the disease improved.

\section{Identification of DNB pathogen and mating types}

At Jahodná, 15 cultures and 15 conidiomata samples were used for Dothistroma species identification. In Jahodná, both Dothistroma species were detected. All conidiomata samples and 14 cultures were identified as D. pini, and only the MAT2 mating type was determined for this

Table 3. Variants of optimal temperature and relative humidity range for the spread of DNB in research plots

\begin{tabular}{|c|c|c|c|c|}
\hline Variant & $\begin{array}{l}\text { Lasting more } \\
\text { than } 10 \text { hours }\end{array}$ & Temperature range & $\begin{array}{l}\text { Relative humidity } \\
\text { range }\end{array}$ & Author \\
\hline V1 & - & $15-20^{\circ} \mathrm{C}$ & $\mathrm{RH}>90 \%$ & DVOŘÁK et al., 2012 \\
\hline $\mathrm{V} 2$ & Yes & $15-20{ }^{\circ} \mathrm{C}$ & $\mathrm{RH}>90 \%$ & GADGIL, 1974 - modified \\
\hline $\mathrm{V} 3$ & - & $10-20{ }^{\circ} \mathrm{C}$ & $\mathrm{RH}>75 \%$ & DvořÁK et al., 2012 \\
\hline V4 & Yes & $10-20{ }^{\circ} \mathrm{C}$ & $\mathrm{RH}>75 \%$ & GADGIL, 1974 - modified \\
\hline V5 & - & $17-22{ }^{\circ} \mathrm{C}$ & $\mathrm{RH}>75 \%$ & BROwn et al., 2012 \\
\hline V6 & Yes & $17-22{ }^{\circ} \mathrm{C}$ & $\mathrm{RH}>75 \%$ & GADGIL, 1974 - modified \\
\hline
\end{tabular}

Table 4. Mean disease intensity (in \%) in individual years of studied period (2014-2018) calculated using the rating system by KIRISITS and FREINSCHLAG (2012) for experimental plots

\begin{tabular}{ccccccc}
\hline Locality & 2014 & 2015 & 2016 & 2017 & 2018 & Increase \\
\hline Jahodná & 50.86 & 55.71 & 59.83 & 66.42 & 68.81 & +17.95 \\
Kálnica & 48.02 & 55.71 & 50.63 & 65.61 & 80.39 & +32.37 \\
Litava & 55.23 & 56.86 & 69.81 & 73.66 & 73.1 & +17.87 \\
\hline
\end{tabular}




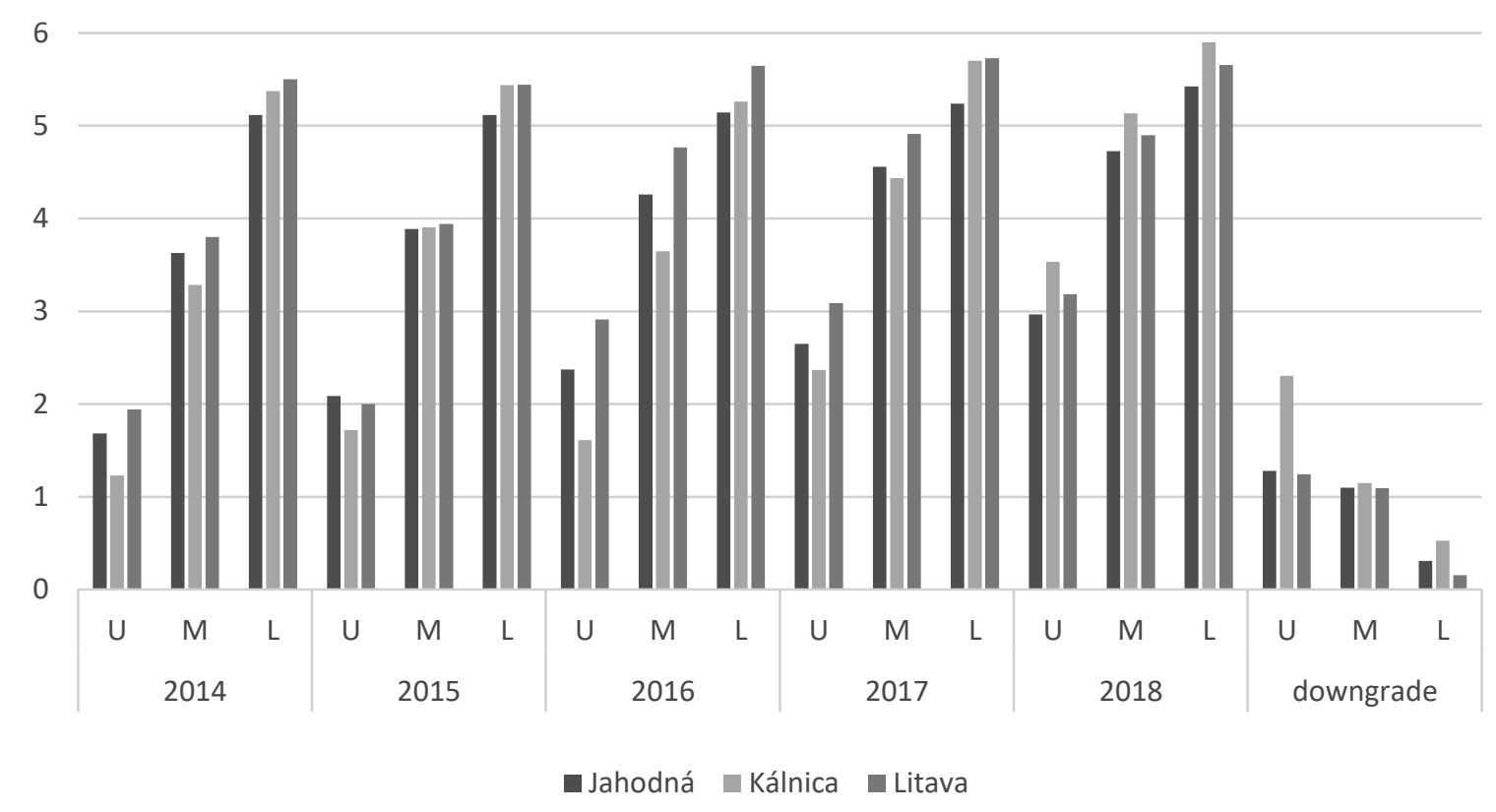

Fig. 2. Disease intensity progression of the upper, middle and lower part of tree crown after 5-year evaluation in Jahodná, Kálnica and Litava localities of Pinus stands caused by DNB. Mean disease intensity expressed by classes (0-6) calculated for the upper, middle and lower third of tree crown during 5 years of evaluations and downgrade in disease intensity calculated as the difference between the first and last evaluation in experimental plots.

species. One culture and two conidiomata samples were positive for D. septosporum; all were identified as MAT2 mating type. These two conidiomata samples gave also positive results for $D$. pini, and one contained conidiomata from the same needle.

At Kálnica, 42 isolates were analysed; only D. septosporum was determined, but both mating types were present in a ratio of 19:23, with a slight dominance of the MAT2 idiomorph.

At Litava, all isolates were identified as D. septosporum. Ten cultures were isolated from P. nigra and only for molecular identification also 2 more cultures from P. sylvestris. Most isolates from P. nigra $(\mathrm{n}=9)$ were MAT 2. One isolate from P. nigra and both from P. sylvestris were identified as the MAT1 mating type.

\section{Analysis and comparison of climatic data and disease intensity (outbreak)}

In the evaluated period, the average temperatures in Jahodná, Kálnica and Litava were 10.62, 9.19 and $8.77^{\circ} \mathrm{C}$, respectively. Comparing the average monthly temperatures in 2014-2017, we determined statistically significant differences among the three sites (Wilcoxon signed-rank test; $\mathrm{p}<0.0001$ ). Out of six variants and five parameters evaluated, only those with high correlations are presented (Table $5)$.

As a result of correlation analysis, we determined relations between disease intensity and weather condition parameters in the experimental plots. The highest relationship of disease intensity (upper third of crown) was determined

Table 5. Correlations (Pearson correlation coefficient, p-value) determined between disease intensity (upper third of crown) and parameters of temperature and relative humidity within studied localities

\begin{tabular}{|c|c|c|c|}
\hline Correlated parameters & Jahodná & Kálnica & Litava \\
\hline Middle third of crown & $0.98(0.02)$ & $0.97(0.03)$ & $0.97(0.03)$ \\
\hline Lower third of crown & $0.86(0.14)$ & $0.86(0.14)$ & $0.96(0.04)$ \\
\hline Average of tree crown & $0.99(0.00)$ & $0.99(0.01)$ & $0.99(0.01)$ \\
\hline V3 - Maximal duration of interval (hours) & $-0.82(0.18)$ & $-0.59(0.41)$ & $-0.97(0.16)$ \\
\hline V3 - Sum of days (days) & $0.97(0.03)$ & $0.93(0.07)$ & $0.99(0.02)$ \\
\hline V4 - Average duration of interval (hours) & $-0.92(0.08)$ & $-0.95(0.05)$ & $-0.95(0.20)$ \\
\hline
\end{tabular}


for parameter Sum of days (variant V3) in all three experimental plots. The V3 interval represented the broadest tested range of optimal temperature and relative humidity for the spread of DNB. Based on these results, we can conclude that out of six intervals evaluated, V3 is the optimal variant for the spread of DNB in the experimental plots.

Based on the negative correlation between disease intensity and V3, Average interval duration implies that a higher number of shorter intervals is crucial for DNB spread. We also observed a low correlation with Number of intervals as well as with Sum of hours, supporting this hypothesis.

In the study area, the critical infection period last from the second half of May until the end of June. During this period, optimal conditions of $\mathrm{RH}$ and temperature were given (for at least 1 hour) from 24 to 30 days of the month in all three localities. For example, in the 2016 season, 25 or more days per month, from May to the end of September, had optimal conditions in all three localities. This finding supports the hypothesis that a higher number of shorter intervals is crucial for DNB spread. Also, Table 3 indicates this conclusion for the V1 interval in 2014.

\section{Discussion}

Based on our results, we can claim that out of six intervals evaluated regarding the spread of DNB pathogens in the experimental plots, the optimal temperature is 10-20 ${ }^{\circ} \mathrm{C}$, with a relative humidity $>75 \%$. The health state of the assessed trees decreased throughout the evaluated period because of optimal environmental conditions for disease outbreak and spore dispersal. Particularly, days with optimal conditions (based on V3 variant) occurred throughout most of the year, with the exception of February 2015, January 2016 and January 2017 for all study sites.

The negative correlation between disease intensity and Average interval duration (V3) implies that a higher number of shorter intervals is crucial for DNB spread. The low correlation with Number of intervals as well as with Sum of hours also supports this hypothesis. Our findings are in agreement with HARVELL et al. (2002), who reported that pathogens causing needle diseases are sensitive to precipitation and humidity and that their rates of reproduction, spread and infection are greater under moist conditions.

According to SincLAIR et al. (1987) and Gilmour (1981), the minimum temperatures for the spread of DNB are $5-10{ }^{\circ} \mathrm{C}$, and optimal temperatures are 15-22 ${ }^{\circ} \mathrm{C}$ (Karadzic, 1994; Brown et al., 2012; DvořáK et al., 2012). However, the necessary condition for sporulation is a high relative humidity, $>75 \%$ (BROwN et al., 2012) or $>90 \%$ (DvoŘÁK et al., 2012). GILMOUR (1981) state that a temporal moisture of needles for minimum 10 hours for successful sporulation of DNB is necessary.

According to BOATENG and LEWIS (2015), an increase in rainfall results in a greater number of disseminated conidia, although rainfall frequency is more important than the amount of rain. These authors conclude that the dispersal of conidia of $D$. septosporum is significantly associated with rainfall, leaf wetness, relative humidity $(\mathrm{RH})$ and temperature; however, no conidia were observed on rainless days regardless of the temperature and $\mathrm{RH}$. Contrary, PETERSON (1967) and KARADZIĆ (1989) claim that in Central Europe, even small amounts of rain are sufficient for spore dispersal, and the amount of rainfall is less important than temperature. Although we did not record rainfall data, based on hourly data of temperature and the high relative humidity, we can conclude that worsening of the health state of trees is in agreement with a high number of short rain periods. The spread of DNB and the continuous worsening of tree health may have been a result of the high density of trees tested at each site.

Therefore, the spread of DNB in our study corresponds with the findings of BROWN and WEBBER (2008), where vertical spread at the same tree as well as spread within and between neighbouring trees were dominant. We therefore assume that rain splash plays an important role in disease intensification in the studied sites (SHAW and ROYLE, 1993).

The dynamics of disease severity was calculated based on the 5 years of investigation. At the first initial assessment, disease intensity was around $50 \%$, worsening by $17-23 \%$ throughout the studied period. The deterioration of the disease intensity in all three assessed localities and the initial disease state suggest that the climatic conditions at the studied localities are suitable for the spread, growth and life cycle of pathogenic fungi causing DNB. The pathogen intensely grows in host tissues, causing needle necrosis and creating new reproductive organs, which are a source of new infections.

All evaluated trees in the present study belonged to the species Pinus nigra. In the last evaluation year (2018), the average disease intensity rate of trees in the locality Litava was close to 5 of the 6 points of the scale; a similar value was recorded in Jahodná. In Kálnica, intensity rate was, on average, 5.13. These results indicate high susceptibility of this pine species to DNB, which is in agreement with previous studies (DRENKHAN et al. 2016; GIBSON, 1979; JANKovsKÝ et al., 2004; JÁNOŠíKOvá-HeČKová et al., 2018; ONDRUŠKOVÁ et al., 2018).

The increased disease intensity was more noticeable on the middle and upper thirds of the crown. The lower parts were already greatly damaged (5-6 points) at the time of the first observation in 2014, likely as a result of higher humidity close to the soil and a higher infection rate from fallen infected needles with acervuli, which are the source of a new infection. Increased stand density, lack of light, the proximity of infected individuals and deficient forest management contributed to insufficient vigour of the lowest part of the observed trees. However, an overall tree damage above $75 \%$ indicates a significant deterioration in health status at all monitored localities.

We successfully extracted DNA from 69 cultures and 15 samples of needle pieces with conidiomata, demonstrated by PCR products. During the study, both DNB pathogens were identified, and $D$. pini was detected only at Jahodná, similar to the findings of JÁNOŠíkováHeČKoví et al. (2018). Our results suggest a restricted distribution range of $D$. pini (one out of three studied localities). On the contrary, D. septosporum was identified in each studied locality, which is in agreement with its wide geographic distribution range (DRENKHAN et al., 2016). In 
locality Kálnica, the mating type ratio was closest to $1: 1$, and in Jahodná, only MAT 2 was present; in Litava, the ratio was 3:9. A mating ratio close to $1: 1$ is a precondition of sexual reproduction of heterothallic fungi such as both Dothistroma species (GROENEWALD et al., 2007). Further close proximity, genetic affinity of fungal isolates of different mating types is also required for sexual reproduction (BARNES et al., 2011).

Dothistroma pini has most often been found in southern regions, such as in Slovenia in native forest stands (PIŠKUR et al., 2013), in Hungary on introduced P. nigra (BARNES et al., 2011) and in France on native P. nigra (FABRE et al., 2012); however, it also occurs in some northern regions of the USA on introduced $P$. nigra (BARNES et al., 2014) and near Rostov in Russia on introduced $P$. pallasiana, $P$. $n i$ gra and $P$. mugo (BARNES et al., 2011). In southern regions, it has mostly been found on native species, and in cooler areas, it only occurs on introduced pine species. This leads us to infer that $D$. pini was introduced and adapted to those regions. The distribution of $D$. pini was strongly related to temperature as the most important climatic factor (FABRE et al., 2012; TOMEŠOvÁ-HAATAJA et al., 2016). High mean summer temperatures strongly correlated with the presence of $D$. pini, and this pathogen was absent in the northern and eastern parts of France as well as in areas at higher elevations (FABRE et al., 2012). In our study, the highest temperature was recorded in Jahodná. Interestingly, this locality was dominated by $D$. pini. In localites with lower average temperatures (Litava, Kálnica), D. septosporum was the agent of DNB. This implies that higher temperatures facilitate the occurrence of $D$. pini.

The simulations presented by MÖYKKYNEN et al. (2017) predict that by 2030, new DNB outbreaks and intensification of current outbreaks will occur in northern Europe (northern Germany, Poland, Baltic countries, southern Scandinavia and Scotland). In southern and Central Europe, Dothistroma species will have reached a steady-state, with little spread to new forests, although disease severity may still be increasing. Over the last 1520 years, forests in Slovakia, also due to climate change, were exposed to an unpredicted frequency and intensity of harmful agents (Správa o lesnom hospodárstve v Slovenskej republike za rok 2018, 2019), and pine stands were exposed to several pathogenic organisms (HeČKová et al., 2010; IVANOvÁ and BERNADOviČová, 2010; Ivanová, 2017; ONDRUŠKOVÁ and RAKÚSOvÁ-SLÁDKOVÁ, 2018). Approaches to manage and mitigate the effects of climate change on forest diseases include the acquisition and/or synthesis of basic knowledge about tree species and pathosystems, as well as the development of better models that will yield more accurate predictions (STURROCK, 2007). Our data can provide a basis for the development of more accurate predictions of the occurrence of DNB in Europe, thus facilitating the establishment of appropriate vegetation control measures.

\section{Acknowledgement}

This work was supported by the Scientific Grant Agency VEGA of the Slovak Academy of Sciences, No. 2/0077/18.

\section{References}

BraDSHAw, R.E., 2004. Dothistroma (red-band) needle blight of pines and the dothistromin toxin: a review. Forest Pathology, 34: 163-185. https://doi.org/10.1111/j.14390329.2004.00356.x

Barnes, I., Crous, P.W., Wingfield, B.D., Wingfield, M.J., 2004. Multigene phylogenies reveal that red band needle blight is caused by two distinct species of Dothistroma, D. septosporum and D. pini. Studies in Mycology, 50: $551-565$.

Barnes, I., Kirisits, T., Wingfield, M.J., Wingfield, B.D., 2011. Needle blight of pine caused by two species of Dothistroma in Hungary. Forest Pathology, 41: 361-369. https://doi.org/10.1111/j.1439-0329.2010.00689.x

Barnes, I., van der Nest, A., Mullett, M.S., Crous, P.W., Drenkhan, R., Musolin, D.L., Wingfield, M.J., 2016. Neotypification of Dothistroma septosporum and epitypification of D. pini, causal agents of Dothistroma needle blight of pine. Forest Pathology, 46: 388-407. https://doi. org/10.1111/efp.12304

Barnes, I., Walla A., Bergdahl, A., Wingfield, M.J., 2014. Four new host and three new state records of Dothistroma needle blight caused by Dothistroma pini in the United States. Plant Diseases, 98 (10): 1443. http://dx.doi. org/10.1094/PDIS-06-14-0606-PDN

Boateng, K., Lewis, K.J., 2015. Spore dispersal by Dothistroma septosporum in northwestern British Columbia. Phytopathology, 105: 69-79. http://dx.doi.org/10.1094/PHYTO-06-13-0175-R

Brown, A., Rose, D., Webber, J., 2003. Red band needle blight of pine. Forestry Commission Information Note 49. Edinburgh: UK Forestry Commission. 6 p.

Brown, A., WebBer, J., 2008. Red band needle blight of conifers in Britain. Research Note. [online]. Edinburgh: UK Forestry Commission. [cited 2020-03-17]. https://www. researchgate.net/publication/242558839

Brown, A., Tubby, K., Mullett, M., Baden, R., 2012. An introduction to Dothistroma needle blight. [online]. UK Forest Research. [cit. 2020-01-30]. https://www.forestresearch.gov.uk/documents/698/DIAROD_052012_ DNB_Brown.pdf

Bulman, L., 2007. Foliar diseases of pine - the New Zealand experience. In JACKSON, M.B. (comp.) Proceedings of the 54 th annual western international forest disease work conference. Smithers, BC, October 2-6 2006. Missoula, MT: US Department of Agriculture, Forest Service, Forest Health Protection, p. 57-60. https://irp-cdn.multiscreensite.com/1463fd0a/files/uploaded/WIFDWC2006.pdf

Drenkhan, R., Tomešová-HaAtaja, V., Fraser, S., BradShaw, R.E., Vahalík, P., Mullett, M.S., Barnes, I., 2016. Global geographic distribution and host range of Dothistroma species: a comprehensive review. Forest Pathology, 46 (5): 408-442. https://doi.org/10.1111/efp. 12290

DvořÁK, M., Drapela, K., JankovskÝ, L., 2012. Dothistroma septosporum: spore production and weather conditions. Forest Systems, 21 (2): 323-328. https://doi.org/10.5424/ fs/2012212-0246

EPPO, 2015. PM 7/46 (3) Lecanosticta acicola (formerly Mycosphaerella dearnessii), Dothistroma septosporum 
(formerly Mycosphaerella pini) and Dothistroma pini. EPPO Bulletin, 45 (2): 163-182. https://doi.org/10.1111/ epp. 12217

Fabre, B., Ioos, R., Piou, D., Marçais, B., 2012. Is the emergence of Dothistroma needle blight of pine in France caused by the cryptic species Dothistroma pini? Phytopathology, 102: 47-54. https://doi.org/10.1094/ PHYTO-02-11-0036

GADGIL, P.D., 1974. Effect of temperature and leaf wetness period on infection of Pinus radiata by Dothistroma pini. New Zealand Journal of Forestry Science, 4: 495-501.

Gäumann, E., 1950. Principles of plant infection. London: Crosby Lockwood. 543 p.

Gibson, I.A., Christensen, P.S., Munga, F.M., 1964. First observation in Kenya of a foliage disease of pines caused by Dothistroma pini Hulbary. Commonwealth Forestry Review, 43: 31-48.

Gibson, I.A.S., 1972. Dothistroma blight of Pinus radiata. Annual Review of Phytopathology, 10: 51-72.

GiBson, I. A.S., 1979. Diseases of forest trees widely planted as exotics in the tropics and South hemisphere. Part II. Genus Pinus. Kew, UK: Commonwealth Mycological Institute, and Oxford: Commonwealth Forestry Institute. $135 \mathrm{p}$.

GiLmour, J.W., 1967. Distribution and significance of the needle blight of pines caused by Dothistroma pini. New Zealand Plant Disease Reporter, 51 (9): 727-730.

GiLmour, J.W., 1981. The effect of season on infection of Pinus radiata by Dothistroma pini. Forest Pathology, 11 (56): 265-269. https://doi.org/10.1111/j.1439-0329.1981. tb00095.x

Groenewald, M., Barnes, I., Bradshaw, R.E., Brown, A.V., Johannes, A.D., Groenewald, Z., Lewis, K.J., Wingfield, B.D., Wingfield, M.J., Crous, P.W., 2007. Characterization and distribution of mating type genes in the Dothistroma needle blight pathogens. Mycology, 97 (7): 825-834. https://doi.org/10.1094/PHYTO-97-7-0825

Harrington, T.C., Winfield, M.J., 1998. Disease and the ecology of indigenous and exotic pines. In Richarson D. (ed.). Ecology and biogeography of Pinus. Cambridge: Cambridge University Press, chapter 19, p. 381-404.

Harvell, C.J., Mitchell, C.E., Ward, J.R., 2002. Climate warming and disease risks for terrestrial and marine biota. Science, 296 (5576): 2158-62. https://doi.org/10.1126/ science. 1063699

HeČKová, Z., AdAmČíkovÁ, K., KošŤÁL, J., 2010. The black pine health condition in the Zoborské vrchy Mts. Folia Oecologica, 37 (2): 162-167. http://ife.sk/wp-content/uploads/2016/10/FO_37_2_Heckovapdf.pdf

Ivanová, H., 2017. Morphological features of Camarosporium pini - the fungus associated to health state degradation in Austrian and Ponderosa pine. Folia Oecologica, 44 (1): 54-57. https://doi.org/10.1515/foecol-2017-0007

Ivanová, H., Bernadovičová, S., 2010. Species diversity of microscopic fungi on Austrian pines growing in urban greenery of Nitra town. Folia Oecologica, 37: 168-180. http://ife.sk/wp-content/uploads/2016/10/FO_37_2_ ivanova.pdf

JankovskÝ, L., PAlovčíková, D., BednáŘová, M., 2004. Picea pungens Engelm. - a new host of Dothistroma needle blight Mycosphaerella pini E. Rostrup detected in the Czech Republic. Journal of Forest Science, 50 (5): 235-236. https://doi.org/10.17221/4619-JFS

Jankovský, L., BednáŘová, M., Palovčíková, D., 2004. Dothistroma needle blight Mycosphaerella pini E. Rostrup, a new quarantine pathogen of pines in the CR. Journal of Forest Science, 50 (7): 319-326. https://doi. org/10.17221/4629-JFS

JÁNoŠíKovÁ-HečKovÁ, Z., OndruŠKová, E., BARTA, M., OsTrovskÝ, R., KÁdASI HorÁKovÁ, M., PASTIRČÁKOvÁ, K., Kobza M., AdamČíková K., 2018. The hosts and geographic range of Dothistroma needle blight in Slovakia. Forest Pathology; 48 (3): e12421. https://doi.org/10.1111/ efp. 12421

KARADŽIĆ, D., 1989. Scirrhia pini Funk and Parker. Life cycle of the fungus in plantations of Pinus nigra Arn. in Serbia. European Journal of Forest Pathology, 19 (4): 231-236. https://doi.org/10.1111/j.1439-0329.1989.tb00257.x

Kirisits, T., Freinschlag, CH., 2012. Ash dieback caused by Hymenoscyphus pseudoalbidus in seed plantation of Fraxineus excelsior in Austria. Journal of Agricultural Extension and Rural Development, 4 (9): 184-191. doi:10.5897/JAERD12.046

KunCA, A., FoffovÁ, E., 2000. Ohrozenie porastov borovice čiernej fytokaranténnym patogénom Dothistroma septospora (Dorog.) Merelet [The threat to Austrian pine plantations from the phytosanitary pathogen Dothistroma septospora (Dorog) Morelet]. In VARÍNSKY, J. (ed.). $A k$ tuálne problémy v ochrane lesa 2000. Zvolen: Lesnícky výskumný ústav, p. 136-139.

Morelet, M., 1968. De aliquibus in mycologia novitatibus (3 note) [Mycology news]. Bulletin de la Societe des Amis du Vieux Toulon Bull, 177: 9.

Möykkynen, T., Fraser, S., Woodward, S., Brown, A., Pukkala, T., 2017. Modelling of the spread of Dothistroma septosporum in Europe. Forest Pathology, 47 (3): e12332. https:/doi.org/10.1111/efp.12332

OndrušKová, E., HeČKová, Z., Kádasi Horáková, M., KoltaY, A., Ostrovský, R., PažitnÝ, J., AdamČíková, K., 2017. Distribution and characterization of Dothistroma needle blight Pathogens on Pinus mugo in Slovakia. European Journal of Plant Pathology, 148 (2): 283-294. https:/doi.org/10.1007/s10658-016-1088-2

ONDRUŠKovÁ, E., RAKúSOvÁ-SLÁDKOvÁ, D. 2018. Poškodenie porastov borovíc hubami rodu Dothistroma na lokalite Banská Belá [Dothistroma sp. damage pine plantation in Banská Belá]. In BARTA, M., ONDRUŠKová, E. (eds). Dreviny vo verejnej zeleni 2018. Recenzovaný zbornik príspevkov z vedeckej konferencie konanej pri príležitosti nedožitých 75. narodenín Doc. Ing. Gabriely Juhásovej, CSc. v Nitre 7. júna 2018. Zvolen: Ústav ekológie lesa SAV, p. 131-139.

OndRuŠKová, E., HeČKovÁ-JÁNošíKovÁ, Z., ADAMČíK, S., Kádasi Horáková, M., RakúSová-SládKová, D., ADAмČíkoví, K., 2018. Needle blight caused by Dothistroma pini in Slovakia: distribution, host range and mating types. Scandinavian Journal of Forest Research, 33 (7): 650-656. https:/doi.org/10.1080/02827581.2018.14 82954

Peterson, G.W., 1967. Dothistroma needle blight of Austria and ponderosa pines: epidemiology and control. Phytopathology, 57: 437-441. 
PišKur, B., Hauptman, T., JurC, D., 2013. Dothistroma needle blight in Slovenia is caused by two cryptic species: Dothistroma pini and Dothistroma septosporum. Forest Pathology. 43 (6): 518-521. https://doi.org/10.1111/ efp. 12059

Shaw, M.W., RoYLE, D.J., 1993. Factors determining the severity of epidemics of Mycosphaerella graminicola (Septoria tritici) on winter wheat in the UK. Plant Pathology, 42 (6): 882-899. https://doi.org/10.1111/j.1365-3059.1993. tb02674.x

Sinclair, W.A., Lyon, H.H., Johnson, W.T., 1987. Diseases of trees and shrubs. London: Comstock Publishing Associates. $616 \mathrm{p}$.

Správa o lesnom hospodárstve $v$ Slovenskej republike za rok 2018, 2019. Zelená správa [Report on forestry in the Slovak Republic for 2018. Green report]. Bratislava: Ministerstvo pôdohospodárstva a rozvoja vidieka Slovenskej republiky. $66 \mathrm{p}$.

Sturrock, R.N., 2007. Climate change effects on forest diseases: an overview. In Proceedings of the 54th annual western international forest disease work conference. Smithers, BC, October 2-6 2006. Missoula, MT: US Department of Agriculture, Forest Service, Forest Health
Protection, p. 51-55. https://irp-cdn.multiscreensite.com/ 1463fd0a/files/uploaded/WIFDWC2006.pdf

Tomešová-HaAtaja, V., BednáŘová, M., Vahalík, P., Palovčíková, D., TomšovskÝ, M., DvoŘÁK, M., JANKovskÝ, L., 2016. Červená sypavka borovice v České republice. Kostelec nad Černými lesy: Lesnická práce s.r.o. 56 p. Woods, A.J., 2003. Species diversity and forest health in northwest British Columbia. The Forestry Chronicle, 79 (5): 892-897. https://doi.org/10.5558/tfc79892-5

Woods, A.J., CoATes, D., Hamann, A., 2005. Is an unprecedented Dothistroma needle blight epidemic related to climate change? BioScience, 55 (9): 761-769. https://doi.org/10.1641/0006-3568(2005)055[0761:IAU DNB]2.0.CO;2

Woods, A.J., Martín-García, J., Bulman, L., Vasconcelos, M.W., Boberg, J., La Porta, N. Peredo, H., Vergara, G., Ahumada, R., Brown, A., Diez, J. J., 2016. Dothistroma needle blight, weather and possible climatic triggers behind the disease's recent emergence, Forest Pathology, 46: 443-452. https://doi.org/10.1111/efp.12248

Received April 10, 2020 Accepted September 29, 2020 